\title{
PENGARUH LAJU SEDIMENTASI TERHADAP REKRUTMEN KARANG DI TELUK KENDARI, PROVINSI SULAWESI TENGGARA (The Effect of Sedimentation Rate on Coral Recruitment in Kendari Bay, Southeast Sulawesi Province)
}

\author{
Subhan $^{1 *}$ dan La Ode Alirman Afu ${ }^{2}$ \\ ${ }^{1}$ Jurusan Manajemen Sumber Daya Perairan, Fakultas Perikanan dan Ilmu Kelautan, \\ Universitas Halu Oleo, Jl. HEA Mokodompit No.1 Kendari 93613 \\ ${ }^{2}$ Jurusan Ilmu Kelautan, Fakultas Perikanan dan Ilmu Kelautan, Universitas Halu Oleo \\ Gedung FPIK-UHO Jl. HEA Mokodompit No.1 Kendari 93613
}

*Penulis korespondensi. No Tel: 08539413 9509. Email: lasubhan@gmail.com

Diterima: 30 November 2016
Disetujui: 19 Maret 2017

\begin{abstract}
Abstrak
Sedimentasi secara terus menerus menjadi masalah utama terumbu karang di perairan pesisir. Sebanyak 7 titik pengambilan sampel telah dilakukan di Teluk Kendari Provinsi Sulawesi Tenggara selama periode Juni - Oktober 2015. Penelitian ini bertujuan membuktikan pengaruh laju sedimentasi terhadap rekrutmen karang baik dalam sebaran kelompok taksa dan ukuran koloni juvenil karang. Pengambilan sampel dengan transek kuadrat mengunakan alat selam SCUBA dilakukan untuk memperoleh data tentang rekrutmen karang, sedangkan pengukuran laju sedimentasi menggunakan metode sediment trap. Hubungan antara laju sedimentasi dengan rekrutmen karang dianalisis dengan menggunakan analisis regresi sederhana. Hasil penelitian menunjukkan terdapat hubungan linier negatif antara laju sedimentasi dan rekrutmen karang yang ditunjukkan dengan nilai koefisien korelasi $r=-0,941$.
\end{abstract}

Kata kunci: rekrutmen karang, laju sedimentasi, hubungan, lingkungan pesisir, Teluk Kendari.

\begin{abstract}
Sedimentation constantly becomes the major problem for coral reefs in coastal areas. There were seven sampling stations carried out in Kendari Bay between June -October 2015. The purpose of the present study was to confirm the effect of sedimentation rate on coral recruitment in the level of genus and size of the colony of coral's juvenile. Sampling was collected using quadrant transect method with the help of SCUBA to obtain data on coral recruitment, while the sedimentation rates were measured using sediment trap method. The relationship between sedimentation rates and coral recruitment was analysed using regression linear. The results showed that there was negative relationship between sedimentation rates and coral recruitment with the coefficient correlation $r=-0.941$.
\end{abstract}

Keywords: coral recruitment, sedimentation rate, relationship, coastal, Kendari bay.

\section{PENDAHULUAN}

Saat ini kondisi perairan Teluk Kendari sangat memprihatinkan. Salah satu penyebab memburuknya kualitas perairan di Teluk Kendari adalah sedimentasi. Beberapa penelitian menunjukkan laju sedimentasi di Teluk Kendari mencapai 110.113,5 $\mathrm{m}^{3} /$ tahun atau 143.148 ton/tahun (Sudrajat, 2010). Pembukaan lahan di daerah aliran sungai yang bermuara ke teluk juga turut berperan dalam meningkatkan erosi permukaan dan merupakan faktor utama yang meningkatkan suplai muatan sedimen melalu muara ke Teluk. Sedimentasi yang terjadi di Teluk Kendari dapat ditandai dengan perairan yang semakin keruh terutama pada lokasi-lokasi yang berdekatan dengan muara sungai dan daratan.

Salah satu ekosistem menerima dampak langsung dari proses sedimentasi adalah terumbu karang. Kekeruhan dari proses sedimentasi berpengaruh terhadap tingkat penetrasi cahaya matahari ke dasar perairan, sehingga akan mempengaruhi proses fotosintesa alga zooxanthela yang bersimbiosis dengan karang, yang pada akhirnya dapat menghambat pertumbuhan ekosistem terumbu karang (Gilmour, 1999; Minton dan Lundgreen, 2006; Humphrey dkk, 2008; DeMartini dkk, 2013). Dampak lebih lanjut dari sedimentasi adalah terganggunya fungsi ekologis terumbu karang sebagai daerah asuhan, memijah dan mencari makan bagi ikan dan organisme laut lainnya (Reid dkk, 2009). Dampak lain yang terjadi adalah kehilangan potensi terumbu karang sebagai sumber biomedik, anti bakteri dan anti kanker untuk keperluan industri farmasi di masa mendatang (Soedharma dkk, 2005).

Selain sedimentasi, faktor alami tak terduga dapat menjadi penyebab kerusakan terumbu karang 


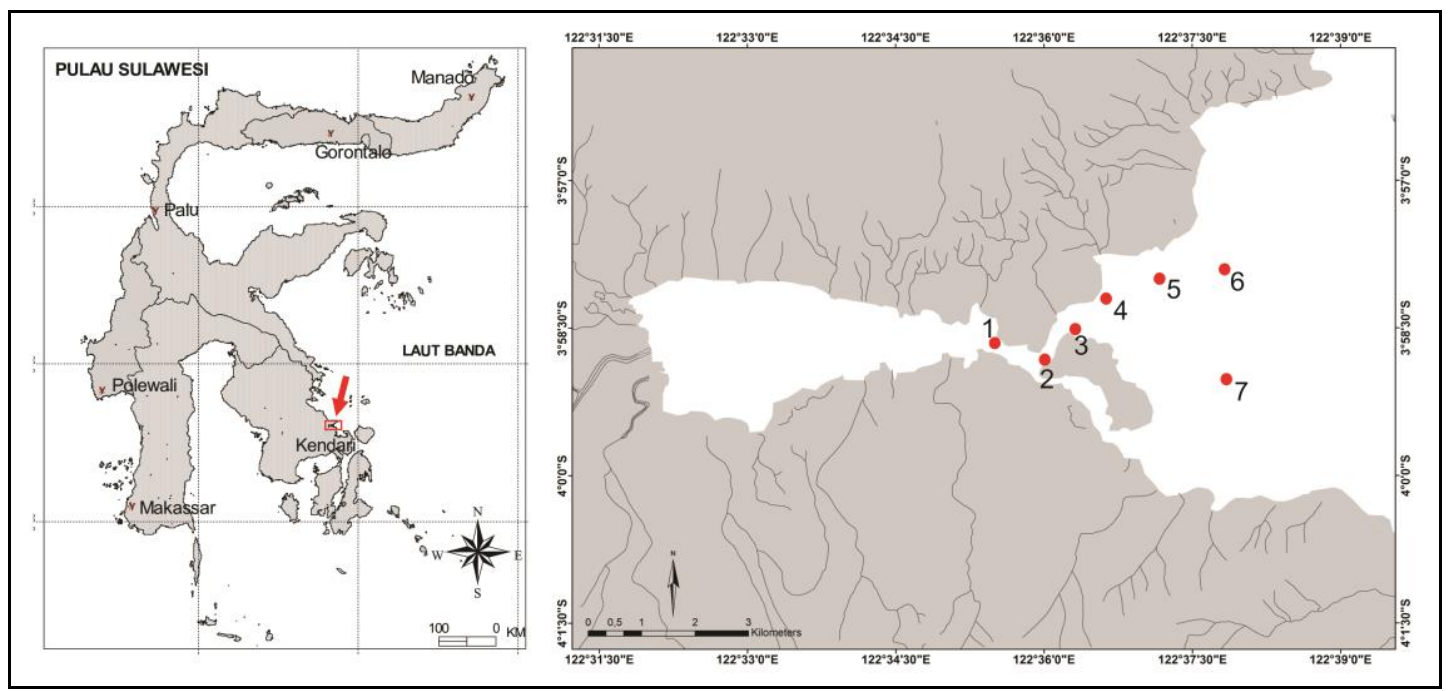

Gambar 1. Lokasi penelitian (angka menunjukkan lokasi pengambilan sampel).

seperti gelombang besar atau tsunami. Purbani dkk (2014) melaporkan kerusakan terumbu karang pasca mega tsunami Aceh di mana tutupan karang hidup di bawah 15\% khusus daerah Ujung Seurawan dan Loh Weng.

Secara alami respon terumbu karang terhadap perubahan dan tekanan lingkungan seperti sedimentasi adalah berusaha bertahan (resistensi) dan menunjukkan gejala pemulihan (recovery) sampai terbentuknya komunitas yang stabil (resilience) dan kembali setelah mengalami kerusakan (Abelson, 2005; Fabricius, 2005; Cameron dan Harrison, 2016). Di alam pemulihan terumbu karang ditandai dengan kemunculan koloni karang muda dengan ukuran koloni relatif kecil. Kemunculan koloni muda ini memberi indikasi telah terjadi penambahan koloni baru (rekrutmen) ke dalam populasi yang berkontribusi nyata dalam pembentukan dan perkembangan komunitas karang selanjutnya (Haywick dan Mueller, 1997; Obura dan Grimsdicth, 2009; Bramanti dan Edmunds, 2016).

Penelitian rekrutmen karang juga telah dilakukan di beberapa perairan, antara lain Pulau Pari, Jakarta (Suharsono, 1995), Kepulauan Seribu (Rudi, 2005), Karimun Jawa (Munasik dkk, 2008), Kepulauan Lembata, Nusa Tenggara Timur (Bachtiar dkk, 2012), di perairan Wakatobi (deLeon dkk, 2013), Kepulauan Mentawai (Abrar, 2005) dan perairan Natuna, Kepulauan Riau (Abrar, 2015). Namun keseluruhan penelitian tersebut belum membahas dampak sedimentasi terhadap rekrutmen karang.

Penelitian tentang pengaruh laju sedimentasi terhadap rekrutmen karang sangat penting dalam menyediakan informasi terhadap strategi konservasi dan teknologi rehabilitasi yang tepat terumbu karang. Selain itu, informasi yang diperoleh juga dapat menjadi dasar pertimbangan "trans-lokasi" karang bagi upaya penyelamatan jangka panjang bagi terumbu karang di Teluk Kendari.

\section{METODE PENELITIAN}

\section{Waktu dan Lokasi}

Penelitian dilaksanakan di perairan Teluk Kendari yang secara administrasi termasuk dalam wilayah Kota Kendari. Penelitian ini berlangsung Juni 2015 - Oktober 2015. Penentuan stasiun diawali dengan survey pendahuluan menggunakan metode manta tow untuk memastikan keberadaan terumbu karang (Hill dan Wilkinson, 2004). Penentuan stasiun pengamatan rekrutmen karang menggunakan metode purposive sampling yang dibedakan dalam 7 lokasi pengamatan dengan pertimbangan keterwakilan wilayah seluruh teluk (Gambar 1). Masing-masing lokasi dilakukan pengulangan sebanyak 3 kali. Pengamatan tidak dilakukan pada area muara dan tengah teluk karena telah dipastikan subtrat lebih didominasi lumpur.

\section{Prosedur \\ Pengukuran Rekrutmen Karang}

Dalam penelitian ini rekrutmen karang adalah semua koloni karang muda atau juvenile yang telah menempel tetap pada subtrat alami. Menurut Abrar dkk (2011), juvenile karang didefinisikan sebagai semua koloni yang dapat dilihat (visible) sampai maksimal diameter kurang atau sama dengan $10 \mathrm{~cm}$. Setiap stasiun pengamatan dibuat Line Intercept Transect (LIT) sepanjang $30 \mathrm{~m}$, sebagai panduan peletakan transek kuadrat (Hill dan Wilkinson, 2004). Pengamatan rekrutmen karang menggunakan transek kuadrat $\left(1 \times 1 \mathrm{~m}^{2}\right)$ ditempatkan secara acak dengan 9 kali ulangan. Sebaran kelimpahan rekrut karang muda dinyatakan dalam satuan koloni $/ \mathrm{m}^{2}$. Pengambilan data dilakukan secara in situ dengan penyelaman 


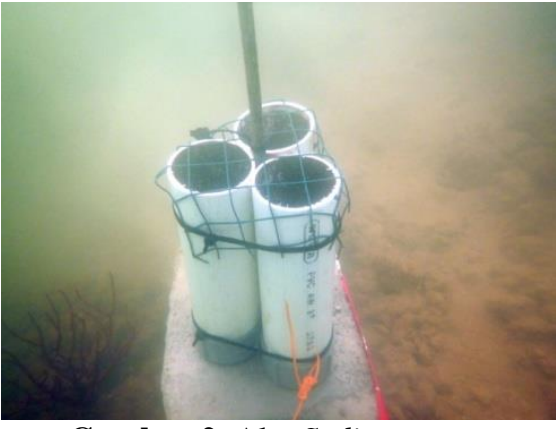

Gambar 2. Alat Sediment trap

SCUBA dan kamera bawah air. Identifikasi rekruit karang dilakukan sampai tingkat genus, karena ukuran koloni relatif kecil, sehingga sulit untuk mengidentifikasi sampai tingkat spesies. Identifikasi rekruit karang dilakukan berdasarkan identifikasi karang mengacu dari Veron (2000) dan Suharsono (2010).

\section{Pengukuran Laju Sedimentasi}

Pengukuran laju sedimentasi di setiap area sampling dilakukan dengan menggunakan alat sediment trap (English dkk, 1997). Sediment trap berbahan pipa PVC berdiameter 2 inchi dan tinggi $25 \mathrm{~cm}$ yang dirakit sedemikian rupa (Gambar 2), ditempatkan di dasar perairan selama 3 bulan. Sedimen yang terkumpul kemudian dikeringkan dalam oven pada suhu $60{ }^{\circ} \mathrm{C}$ selama 24 jam. Selanjutnya dilakukan penyaringan bertingkat dan pengukuran berat kering sedimen dalam satuan miligram dengan timbangan analitik. Laju sedimentasi dinyatakan dalam satuan $\mathrm{mg} / \mathrm{cm}^{2} / \mathrm{hari}$ (Adriman dkk, 2013).

\section{Analisis Data}

Perhitungan rekurutmen karang dilakukan dengan menggunakan persaman sebagai berikut :

$R=\frac{\sum_{i=1}^{S} n_{i}}{A}$

Keterangan :

$\mathrm{R}=$ Kepadatan rekrutmen karang $\left(\mathrm{koloni} / \mathrm{m}^{2}\right)$

$\mathrm{n}_{\mathrm{i}}=$ jumlah koloni jenis karang ke- $i$

$\mathrm{s}=$ jumlah jenis karang

$\mathrm{A}=$ luas transek kuadrat $\left(\mathrm{m}^{2}\right)$

Perhitungan laju sedimentasi di ekosistem terumbu karang dilakukan melalui persamaan berikut :

$L S=\frac{B S}{\text { jumlah hari } \times \pi r^{2}}$

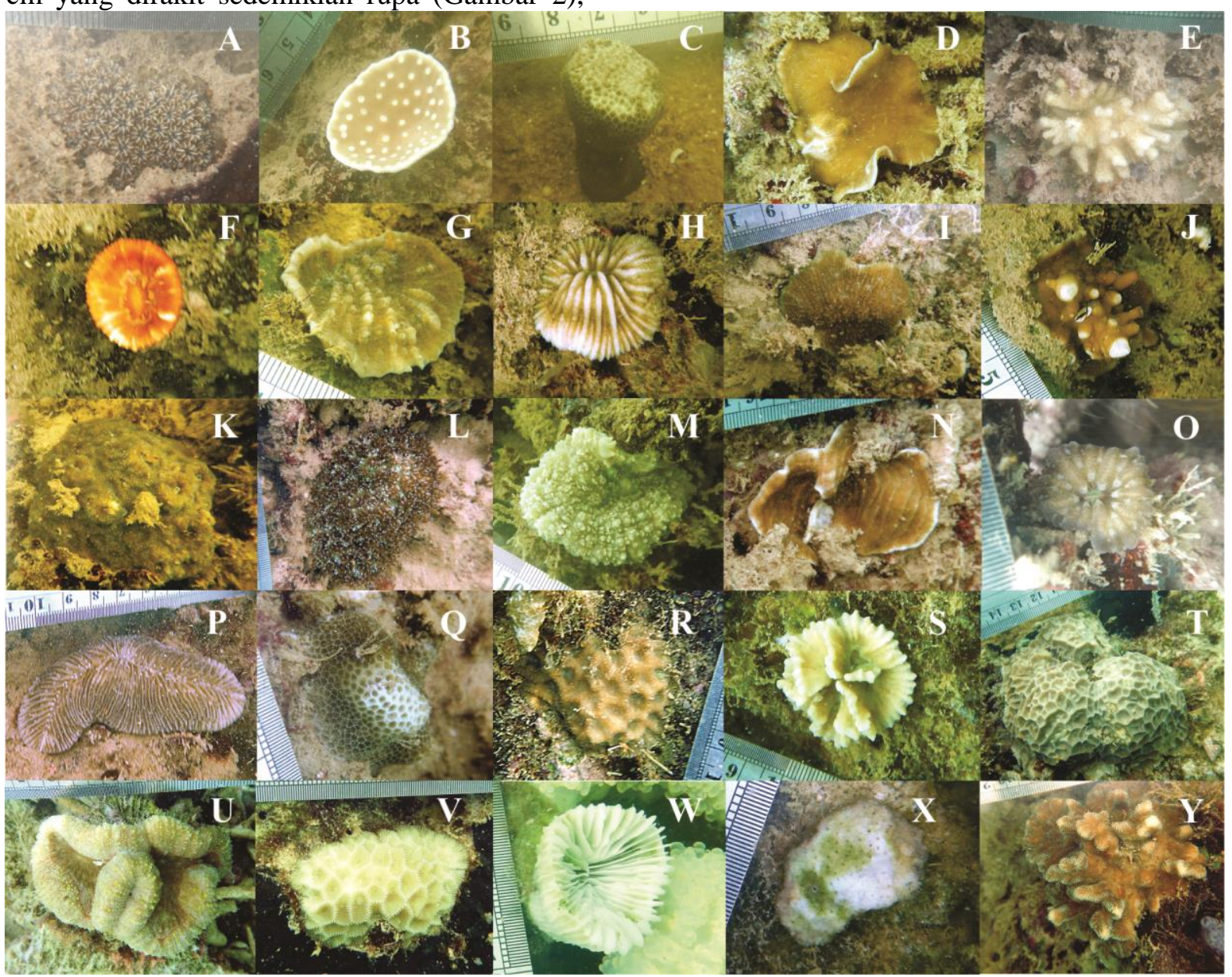

Gambar 3. Beberapa genera karang dari hasil pengamatan. Keterangan : A=Oulastreacrispata, B=Turbinaria, $\mathrm{C}=$ Porites, $\mathrm{D}=$ Pavona, $\mathrm{E}=$ Pocillopora, $\mathrm{F}=$ Dendrophyllia, $\mathrm{G}=$ Echinophyllia, $\mathrm{H}=$ Fungia, $\mathrm{I}=$ Halomitra, J=Acropora, $\mathrm{K}=$ Favia, $\mathrm{L}=$ Galaxea, $\mathrm{M}=$ Montastrea, $\mathrm{N}=$ Pachyseris, $\mathrm{P}=$ Ctenactis, $\mathrm{Q}=$ Leptastrea, $\mathrm{S}=$ Pectinia, U=Lobophyllia, $\mathrm{V}=$ Favites, $\mathrm{W}=$ Euphyllia, $\mathrm{X}=$ Psammocora $\mathrm{Y}=$ Merulina 
Keterangan :

$L S=$ laju sedimentasi $\left(\mathrm{mg} / \mathrm{cm}^{2} /\right.$ hari $)$

$B S=$ berat kering sedimen $(\mathrm{mg})$

$\pi=$ konstanta $(3,14)$

$\mathrm{r}=$ jari-jari lingkaran sediment trap $(\mathrm{cm})$

Hubungan antara laju sedimentasi dengan rekrutmen karang, dilakukan analisis regresi linear dengan menggunakan software Microsoft Excel 2007. Dalam penelitian ini yang menjadi variabel terikat adalah rekrutmen karang, sedangkan yang menjadi variabel bebas adalah laju sedimentasi. Secara matematis rumus regresi dapat ditulis sebagai berikut (Walpole, 1995):

$\mathrm{Y}=\mathrm{a}+\mathrm{bX}$

Dengan :

$\mathrm{Y}=$ variabel terikat (rekrutmen karang)

$\mathrm{X}=$ variabel bebas (laju sedimentasi)

$\mathrm{a}=$ intersep (perpotongan garis regresi dengan

sumbu Y)

$\mathrm{b}=$ koefisien regresi.

\section{HASIL DAN PEMBAHASAN}

Hasil pengamatan di tujuh lokasi sampling memperlihatkan variasi rekrut karang muda yang berbeda satu sama lain. Total sebanyak 36 genus dari 13 famili karang berhasil diidentifikasi dari tujuh stasiun pengamatan di Teluk Kendari. Kenakaragaman rekrut karang tersebut lebih rendah dibanding penelitian lain di Indonesia. Penelitian di Kepulauan Natuna, Provinsi Kepulauan Riau, menemukan 41 genus karang yang mewakili 14 famili (Abrar, 2015). Penelitian Bachtiar dkk, (2012) di perairan Lembata, Nusa Tenggara Timur mendapat jumlah genus yang lebih rendah 30 genus dari 13 famili. Meskipun rekrutmen jumlah genus rekrut karang lebih rendah, namun keadaan tersebut memberikan gambaran masih berlanjutnya regenarasi populasi karang di Teluk Kendari.

Jika ditinjau dalam skala lokal, stasiun 1 memiliki jumah kekayaan jenis paling sedikit, hanya 3 genus yang ditemukan pada lokasi ini (Genus Porites, Oulastrea, Turbinaria) dengan dengan ukuran diameter koloni 25-35 mm (Gambar 4). Stasiun 5 memiliki jumlah kekayaan genus tertinggi dengan 17 Genus karang yang berhasil teramati dengan variasi ukuran dimeter koloni lebih beragam antara $5-60 \mathrm{~mm}$. Jika diurut dari jumlah genus berdasarkan famili, ditemukan Favidae ( 9 genus), Pectinidae (5 genus), Fungidae (4 genus), Agaricidae (3 genus), Acroporidae, Caryophyllidae, Mussidae, Pocilloporidae masing-masing (2 genus). Jumlah genus paling sedikit dari Famili Dendrophyllidae, Siderastreidae, dan Trachyphyllidae, masing-masing 1 genus.

Famili dari Genus Favidae secara kuantitas memiliki tingkat kemunculan relatif tinggi dibanding famili lainnya. Favidae merupakan famili

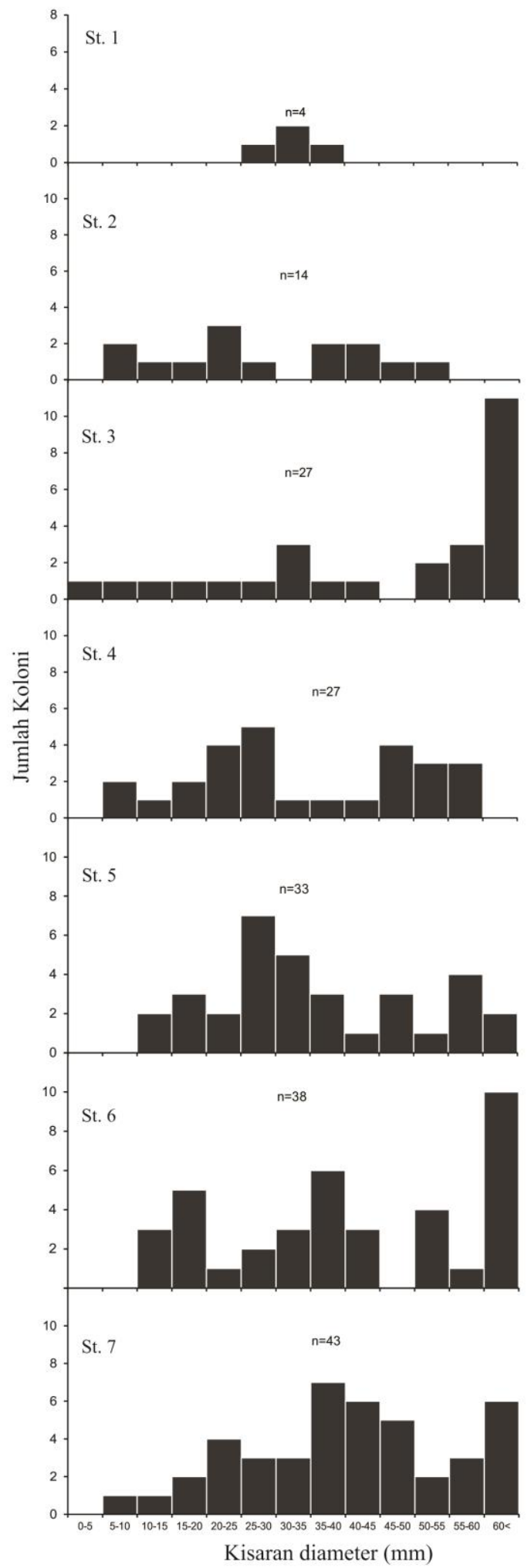

Gambar 4. Sebaran ukuran diameter koloni rektrut karang muda pada masing-masing stasiun pengamatan

dari ordo karang keras (Scleractinia) yang memiliki genus paling banyak (Veron 2000; Suharsono, 2010) sehingga peluang kemunculannya relatif tinggi. Selain itu, genus-genus dalam famili Favidae pada umumnya berbentuk masif dan sub masif dengan ukuran polip lebih besar serta menunjukkan tipe reproduksi hermaphroditel gonochoric spawning broadcasting. Koloni karang dengan 
Tabel 1. Jumlah famili, genus, total koloni dan kepadatan rekruit karang di Teluk Kendari

\begin{tabular}{ccccc}
\hline Lokasi & $\begin{array}{c}\text { Jumlah } \\
\text { Famili }\end{array}$ & $\begin{array}{c}\text { Jumlah } \\
\text { Genus }\end{array}$ & $\begin{array}{c}\text { Jumlah rekruit } \\
\text { karang }\end{array}$ & $\begin{array}{c}\text { Kepadatan rekruit karang } \\
\left(\text { koloni/m }{ }^{2}\right)\end{array}$ \\
\hline Stasiun 1 & 3 & 3 & 4 & $1,3 \pm 0,63$ \\
Stasiun 2 & 5 & 5 & 14 & $4,7 \pm 0,95$ \\
Stasiun 3 & 3 & 5 & 27 & $9,0 \pm 2,81$ \\
Stasiun 4 & 8 & 15 & 27 & $9,0 \pm 1,62$ \\
Stasiun 5 & 10 & 17 & 33 & $14,3 \pm 2,87$ \\
Stasiun 6 & 11 & 14 & 38 & $11,0 \pm 1,98$ \\
Stasiun 7 & 9 & 15 & 43 & $12,7 \pm 2,18$ \\
\hline
\end{tabular}

bentuk masif dan ukuran polip besar lebih tahan terhadap tekanan lingkungan seperti sedimentasi dan perubahan suhu, sedangkan kelompok karang dengan tipe reproduksi seksual gonochoric spawning broadcasting memiliki jarak sebaran larva lebih jauh, serta kelangsungan hidup yang lebih tinggi (Soto dan Weil, 2009; Abrar, 2015).

Di setiap lokasi, kepadatan rekrut karang terlihat bervariasi dan beberapa lokasi menunjukkan perbedaan yang nyata. Kepadatan rekrut karang di stasiun 1 berada dalam kisaran $1,3 \pm 0,63 \mathrm{koloni} / \mathrm{m}^{2}$, sangat rendah dari keseluruhan stasiun pengamatan. Selain itu, terlihat adanya gradasi peningkatan jumlah kepadatan rekrut karang ke arah luar teluk, di mana kepadatan rekrut karang mencapai $14,3 \pm 2,87 \mathrm{koloni} / \mathrm{m}^{2}$ pada stasiun 5 dan 12,7 $\pm 2,18 \mathrm{koloni} / \mathrm{m}^{2}$ pada stasiun 7 (Tabel 1). Diduga kuat tingginya tingkat sedimentasi pada area di dalam teluk menjadi penyebab rendahnya nilai kepadatan rekrut karang. Sebagai perbandingan, perairan Wakatobi dengan kondisi perairan jernih dan minim sedimentasi, kepadatan rekrut karang dapat mencapai $22,15 \mathrm{koloni} / \mathrm{m}^{2}$ (deLeon dkk, 2013). Pada beberapa lokasi terumbu di perairan Samudra Atlantik bagian barat, termasuk Mesoamerican Barrier Reef System (MBRS), Quintana Roo, Mexico, diperoleh kepadatan rekruit karang yang berkisar $0,8-274 \mathrm{koloni} / \mathrm{m}^{2}$ (Zarate dan Gonzales, 2004).

Nilai rekrutmen karang yang rendah pada area di dalam teluk dapat dihubungkan dengan proses sedimentasi yang terjadi. Hasil analisis sampel sedimen kering yang menunjukkan variasi ukuran butiran yang berbeda antara di dalam dan di luar teluk. Sampel sedimen yang berasal dari dalam teluk (Gambar 5a), butiran sedimen didominasi ukuran < $63 \mu \mathrm{m}$, fraksi ukuran butiran mendominasi sampai $40 \%$. Hal ini memberikan gambaran bahwa kondisi perairan relatif terlindung, tidak terlalu berarus dan substart dominasi oleh lumpur (clay). Substrat lumpur merupakan subtrat yang labil bagi pelekatan larva karang (Haywick dan Mueller, 1997; Abelson dkk, 2005; Minton dan Lundgren, 2006). Selain itu, subtrat yang labil membuat partikel subtrat mudah teraduk saat arus
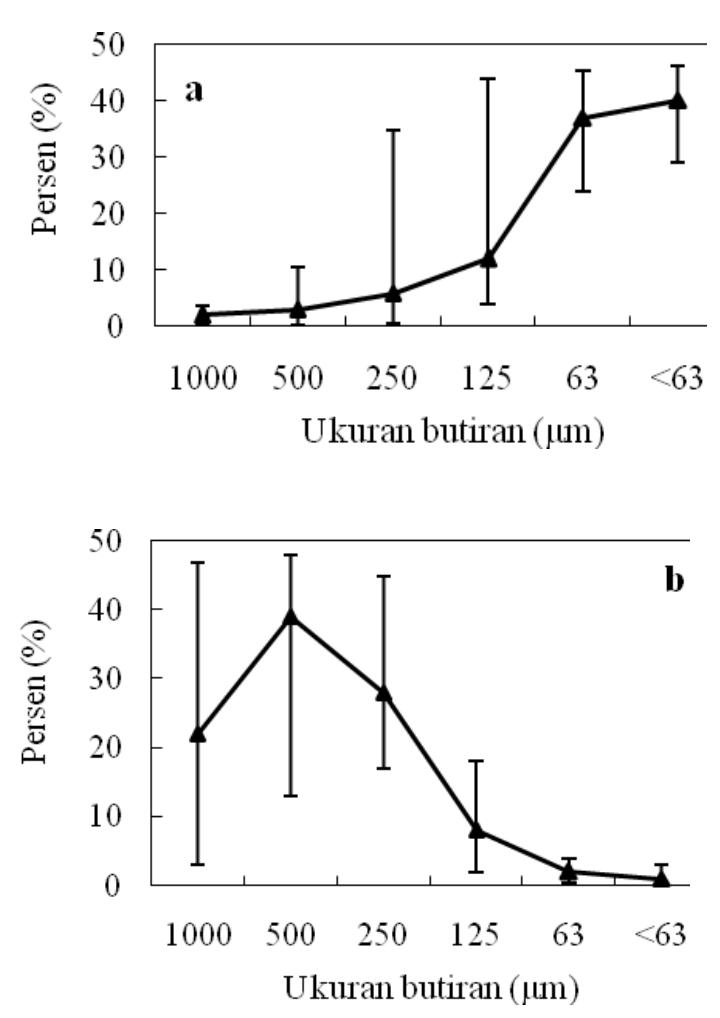

Gambar 5. Distribusi ukuran partikel sedimen (a) di dalam teluk mewakili stasiun 1,2,3 dan (b) di area terumbu karang luar teluk mewakili stasiun 4,5,6,7.

pasang-surut, menyebabkan kekeruhan tinggi. Kekeruhan yang tingi akan menghalangi penetrasi cahaya akibat banyaknya partikel tersuspensi dalam kolom air. Sementara, cahaya merupakan unsur penting bagi pertumbuhan karang karena dibutuhkan oleh alga simbion karang zooxanthella dalam proses fotosintesis (Reid dkk, 2009). Kondisi yang berbeda ditunjukkan pada area perairan di luar teluk. Ukuran butiran sedimen didominasi 500$1000 \mu \mathrm{m}$ (Gambar 5b), menandakan kondisi substrat berpasir, perairan yang cukup berarus dan terbuka. Kondisi perairan relatif jernih dan berarus sangat baik bagi pertumbuhan juvenil karang pasca setlement (pelekatan) (Fabricius, 2005).

Variasi nilai rekrutmen karang antar stasiun sangat dipengaruhi oleh pengaruhi laju sedimentasi yang terjadi. Hasil analisis regresi pada Gambar 6, memperlihatkan korelasi negatif antara laju sedimentasi dengan rekrutmen karang. Nilai 
rekrutmen karang cenderung semakin menurun dengan meningkatnya laju sedimentasi $(r=-0,941)$. Dari model tersebut, jika laju sedimentasi telah mencapai ambang batas $0,061 \mathrm{mg} / \mathrm{cm}^{2} /$ hari maka dipastikan rekrutmen karang tidak akan terjadi pada lokasi tersebut. Sebagai perbandingan, penelitian yang dilakukan Adriman dkk, (2013) di Kawasan Konservasi Laut Bintan Timur, Riau memperlihatkan bahwa laju sedimentasi berpengaruh negatif terhadap tutupan karang. Kisaran laju sedimentasi 4,528 - 108,690 $\mathrm{m} / \mathrm{cm}^{2} /$ hari berpengaruh pada sebaran tutupan karang hidup dalam kisaran di bawah 50\%.

Sedimentasi dapat mencegah pembentukan karang dalam beberapa cara, Pertama, reproduksi karang melalui produksi dan pelepasan larva tergantung pada larva dapat menetap pada substrat yang solid dalam rangka untuk mempersiapkan fondasi bagi pertumbuhannya, di mana ini tidak akan terjadi jika sedimentasi meliputi dasar dengan lumpur halus. Selanjutnya, setelah larva melekat dan membentuk koloni, sedimentasi selanjutnya dapat menyebabkan karang menjadi tertutupi (Fabricius, 2005; Minton dan Lundgren, 2006; Kuo dan Soong, 2010, Goodwin, 2011).

Area dengan sedimentasi tinggi sejalan tingkat dengan tingkat kekeruhan yang terjadi. Kekeruhan memiliki pengaruh tidak lansung terhadap densitas zooxanthella pada karang jenis Acropora, di mana keberadaan padatan tersuspensi menyebabkan penurunan intensitas cahaya yang sampai pada zooxanthella (Thamrin dkk, 2004). Cahaya yang tersedia hanya bisa dimanfaatkan oleh zooxanthella dalam jumlah yang terbatas untuk berfotosinstesis. Sifat zooxanthella yang sangat sensitif terhadap perubahan berbagai faktor secara tidak langsung menyebabkan karang menjadi organisme yang sangat terhadap perubahan lingkungan seperti sedimentasi. Hubungan antara zooxanthella dan karang bersifat saling menguntungkan (simbiosis mutualisme) tidak secara permanen. Zooxanthella hidup di dalam jaringan tubuh karang sepanjang menguntungkan, dan zooxanthella akan secepatnya meninggalkan tubuh karang inang bila keadaan lingkungan mengalami perubahan (Humphrey dkk, 2008; DeMartini dkk, 2013). Hal ini menjadi salah satu pembatas bagi kelulusan hidup juvenil karang yang melekat.

Sesungguhnya karang memiliki mekanisme alami untuk menghilangkan sejumlah kecil sedimen yaitu dengan memproduksi muсus (lendir), tapi respon ini tidak bisa mengatasi dengan jumlah yang lebih besar karena dapat menghalangi proses makan dari karang itu sendiri. Namun, karang tidak dapat terus-menerus memproduksi mucus dengan kualitas dan kuantitas yang sama (Soto dan Weil, 2009; Kuo dan Soong, 2010). Produksi mucus akan dua kali lebih banyak pada jaringan epidermis untuk membersihkan partikel sedimen yang menempel (Fabricius, 2005). Selain itu, padatan tersuspensi yang mengendap menutupi karang tetap mempengaruhi aspek hidup karang yang bersangkutan seperti pertumbuhan, reproduksi, dan proses fisiologis lainnya. Penimbunan sedimen diatas koloni karang membutuhkan energi yang banyak bagi karang untuk membersihkannya. Karena energi yang seharusnya digunakan untuk proses fisiologi tertentu akan dialihkan untuk membersihkan diri dari sedimen yang menutupi karang (DeMartini dkk, 2013). Hal inilah yang akan memperlambat laju pertumbuhan serta mengurangi ketersediaan energi untuk proses reproduksi.

Meskipun demikian, beberapa jenis karang telah mengembangkan proses adaptasi fisiologis terhadap kekeruhan dan sedimentasi. Karang Palythoa spp menghimpun partikel sedimen dengan ukuran tertentu sampai di bawah lapisan mesoglea dan menyatu dengan endapan kalsit lainnya sebagai deposit rangka kapur (Haywick dan Mueller, 1997).

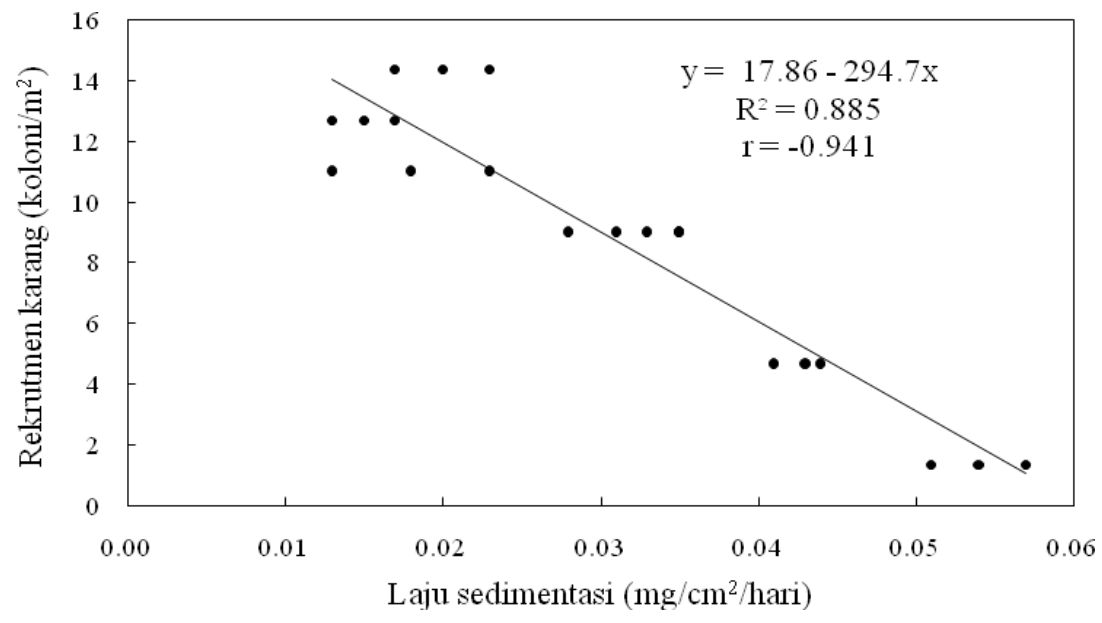

Gambar 6. Pengaruh laju sedimentasi terhadap rekrutmen karang. 
Namun, beberapa jenis karang belum diketahui proses adaptasinya tetapi mampu beradaptasi dengan baik pada area dengan laju sedimentasi relatif tinggi, seperti dalam penelitian ini jenis Porites, Turbinaria, Oulastrea crispata. Suharsono (2008) menjelaskan distribusi Oulastrea crispata di mana jenis ini biasa dijumpai pada daerah yang keruh berlumpur, tidak mudah untuk dijumpai, dan tersebar di seluruh perairan Indonesia.

Pengaruh sedimentasi yang terjadi pada terumbu karang telah disimpulkan oleh beberapa peneliti, terdiri atas: menyebabkan kematian karang apabila menutupi atau meliputi seluruh permukaan karang dengan sedimen; mengurangi pertumbuhan karang secara langsung; menghambat planula karang untuk melekatkan diri dan berkembang di substrat; dan meningkatkan kemampuan adaptasi karang terhadap sedimen.

\section{KESIMPULAN}

Keberadaan terumbu karang dengan kondisi laju sedimentasi yang tinggi mengakibatkan kehadiran rekrut karang muda semakin berkurang atau bahkan rekrutmen tidak terjadi, dengan kata lain nilai rekrutmen karang cenderung semakin menurun dengan meningkatnya laju sedimentasi.

\section{UCAPAN TERIMAKASIH}

Ucapan terima kasih diberikan kepada Program Penelitian dan Pengabdian Kepada Masyarakat Kementerian Ristekdikti (Nomor kontrak : 043/SP2H/LT/DRPM/III/2016) yang telah mendanai penelitian ini. Terima kasih kepada Laboratorium Fakultas Matematika dan Ilmu Pengetahuan Alam (FMIPA) Universitas Halu Oleo dalam memfasilitasi analisa sedimen. Terima kasih yang sebesar-besarnya kepada SSI-Alexa Scuba atas bantuannya dalam penyediaan peralatan selam.

\section{DAFTAR PUSTAKA}

Abelson, A., Olinky, R., dan Gaines, S., 2005. Coral Recruitmen to The Reefs of Eliat, Red Sea: Temporal and Spasial Variation and Possible Effect of Anthropogenic Disturbances. Marine Polution Buletin, 50:576-582.

Abrar, M., 2005. Pemulihan Populasi Karang Setelah Pemutihan di Perairan Sipora, Kepulauan Mentawai, Sumatera Barat. Widyariset, 8(1):60- 72.

Abrar, M., Zamani, N.P., dan Nurjaya, I.W., 2011. Coral Recruitmen, Survival and Growth of Coral Species at Pari Island, Thousand Islands,
Jakarta : a case study of coral resilience. Journal of Indonesia Coral Reefs, 1(1):7-14.

Abrar, M., 2015. Recruitment of Hard Coral (Scleractinia) in Natuna Waters, Riau Islands Province. Oseanologi dan Limnologi di Indonesia, 41(2):133-147

Adriman, Purbayanto, A., Budiharso, S., dan Damar, A., 2013. Pengaruh Sedimentasi Terhadap Terumbu Karang di Kawasan Konservasi Laut Daerah Bintan Timur Kepulauan Riau. Berkala Perikanan Terubuk, 41(1):90-101.

Bachtiar, I., Abrar, M., dan Budiyanto, A., 2012. Rekrutmen Scleractinia di Perairan Lembata, Nusa Tenggara Timur. Indonesian Journal of Marine Science, 17 (1):1-7

Bramanti, L., dan Edmunds, P.J., 2016. DensityAssociated Recruitment Mediates Coral Population Dynamics on a Coral Reef. Coral Reefs, 35:543-553.

Cameron, K.A., dan Harrison, P.L., 2016. Patterns of Scleractinian Coral Recruitment at Lord Howe Island, an Isolated Subtropical Reef of Eastern Australia. Coral Reefs, 35:555-564.

de-Leon, P.S., Dryden, C., Smith, D.J., dan Bell, J.J., 2013. Temporal and Spatial Variability in Coral Recruitment on Two Indonesian Coral Reefs: Consistently Lower Recruitment to a Degraded Reef. Marine Biology, 160(1):97105

DeMartini, E., Jokiel, P., Beets, J., Stender, Y., Storlazzi C., Minton, D., dan Conklin, E., 2013. Terrigenous Sediment Impact on Coral Recruitment and Growth Affects the Use of Coral Habitat by Recruit Parrotfishes (F. Scaridae). Journal of Coastal Conservation, 17:417-429.

English, S.C., Wilkinson, W., dan Baker V., 1994. Survey Manual for Tropical Marine Resources. Australian Institute of Marine Science, Townsville, pp 39-40

Fabricius, K.E., 2005. Effects of Terrestrial Run-off on the Ecology of Coral and Coarl Reefs: Review and Synthesis. Marine Pollution Bulletin, 50:125-146.

Gilmour, J., 1999. Experimental Investigation Into The Effects of Suspended Sediment on Fertilisation, Larval Survival and Settlement in a Scleractinian Coral. Marine Biology, 135:451-462.

Goodwin, E.J., 2011. International Environmental Law and the Conservation of Coral Reefs. Routledge, New York, pp 9-10.

Haywick, D.W., dan Mueller, E.M., 1997. Sediment Retention in Encrusting Palythoa 
spp. - A Biological Twist to a Geological Process. Coral Reefs, 16:39-46

Hill, J., dan Wilkinson. W., 2004. Method for Ecological Monitoring of Coral Reef. Australian Institute of Marine Science, Townsville, pp 238-239

Humphrey, C., Weber, M., Lott, C., Cooper, T., dan Fabricius, K., 2008. Effects of Suspended Sediments, Dissolved Inland Salinity on Fertilisation and Embryo Acropora millepora (Ehrenberg, 1834). Coral Reefs, 27:837-850

Kuo, K.M., dan Soong, K.M., 2010. PostSettlement Survival of Reef-Coral Juveniles in Southern Taiwan. Zoological Studies, 49(6):724-734.

Minton, D., dan Lundgren, I., 2006. Coral Recruitment and Sedimentation in Asan Bay and War in the Pacific NHP, Guam. Report prepared for the National Park Service, Guam, p 1-29.

Munasik, Suharsono, Situmorang, J., dan Kamiso, H.N., 2008. Timing of Larval Release by Reef Coral Pocillopora damicornis at Panjang Island, Central Java. Marine Research in Indonesia, 33(1):33-39.

Obura, D., dan Grimsditch G. 2009. Resilience Assessment of Coral Reefs : Rapid Assessment Protocol for Coral Reefs, Focusing on Coral Bleaching and Thermal Stress. IUCN, Gland, Switzerland, pp 70-71.
Purbani, D., Kepel, T.L., dan Takwir, A. 2014. Kondisi Terumbu Karang di Pulau Weh Pasca Bencana Mega Tsunami. Jurnal Manusia dan Lingkungan, 21(3): 331-340.

Reid, C., Marshall, J., Logan, D., dan Kleine, D. 2009. Coral Reef and Climate Change, The Guide for Education and Awarennes. Coral Watch, University of Queensland, p 272.

Rudi, E., Soedharma, D., Sanusi, H.S., dan Periwono J.J. 2005. Affinitas Penempelan Larva Karang (Scleractinia) pada Subtrat Keras. Jurnal Ilmu-Ilmu Perairan dan Perikanan Indonesia, 12(2):129-137.

Shoedharma, D., Kawaroe, M., Haris, A., 2005. Kajian Potensi Bioaktif Karang Lunak (Octocorallia: Alcyonacea) di Perairan Kepulauan Seribu, DKI Jakarta. Jurnal IlmuIlmu Perairan dan Perikanan Indonesia, 12:121-128.

Soto, E.I., dan Weil, E., 2009. Spatial and Temporal Variability in Juvenile Coral Densities, Survivorship and Recruitment in $\mathrm{La}$ Parguera, Southwestern Puerto Rico. Caribean Journal of Science, 45(2-3):269-281.

Sudrajat, C., 2010. Kajian Sedimentasi di sekitar Muara Sungai Wanggu Teluk Kendari Sulawesi Tenggara. Tesis. Program Studi Pengelolaan Sumber Daya Air, Institut Tehnologi Bandung. Bandung. 